\title{
Complement genetics, deficiencies, and disease associations
}

\author{
Karine R. Mayilyan \\ Institute of Molecular Biology, Armenian National Academy Sciences, Yerevan 0014, Armenia \\ $\triangle$ Correspondence: k_mayilyan@mb.sci.am \\ Received March 16, 2012 Accepted June 7, 2012
}

\section{ABSTRACT}

The complement system is a key component of innate immunity. More than $\mathbf{4 5}$ genes encoding the proteins of complement components or their isotypes and subunits, receptors, and regulators have been discovered. These genes are distributed throughout different chromosomes, with 19 genes comprising three significant complement gene clusters in the human genome. Genetic deficiency of any early component of the classical pathway (C1q, C1r/s, C2, C4, and C3) is associated with autoimmune diseases due to the failure of clearance of immune complexes (IC) and apoptotic materials, and the impairment of normal humoral response. Deficiencies of mannan-binding lectin (MBL) and the early components of the alternative (factor D, properdin) and terminal pathways (from C3 onward components: C5, C6, C7, C8, C9) increase susceptibility to infections and their recurrence. While the association of MBL deficiency with a number of autoimmune and infectious disorders has been well established, the effects of the deficiency of other lectin pathway components (ficolins, MASPs) have been less extensively investigated due to our incomplete knowledge of the genetic background of such deficiencies and the functional activity of those components. For complement regulators and receptors, the consequences of their genetic deficiency vary depending on their specific involvement in the regulatory or signalling steps within the complement cascade and beyond. This article reviews current knowledge and concepts about the genetic load of complement component deficiencies and their association with diseases. An integrative presentation of genetic data with the latest updates provides a background to further investigations of the disease association investigations of the complement system from the perspective of systems biology and systems genetics.

KEYWORDS complement system, deficiency, disease association, HLA-III, RCA

\section{INTRODUCTION}

The complement system serves as the backbone of innate immunity and supports adaptive immune system in gaining its momentum to respond. At present, more than 40 components of this system have been discovered. By opsonising invading microorganisms (e.g. bacteria, viruses, and fungi) or transformed/damaged host materials (e.g. apoptotic and necrotic cells and their fragments), the complement system marks them and provides signals for their removal by the phagocytes of the innate immune system. Complement activation via any of three pathways (classical, alternative, and lectin) promotes stimulation and chemotaxis of leucocytes, and lysis and clearance of relevant targets (Fig. 1). The complement system also serves as a bridge between innate and adaptive immunity by enhancing B-lymphocyte response and augmenting their memory, as well as regulating T-lymphocyte activity (Mayilyan et al., 2008). Beyond its role in immunity, the complement system mediates a wide range of functions in the context of morphogenetic or tissue remodelling processes (Langer et al., 2010). Thus, recent observations implicate the involvement of complements in novel, non-inflammatory functions in the brain, such as basal and ischemia-induced neurogenesis (C3; Rahpeymai et al., 2006) and synapse remodelling and pruning (C1q and C3; Stevens et al., 2007).

In the classical pathway, the recognition protein $(\mathrm{C} 1 \mathrm{q})$ binds to the charged clusters of targets, thus resulting in the activation of the proteases $\mathrm{C} 1 \mathrm{r}$ and $\mathrm{C} 1 \mathrm{~s}$. Activated $\mathrm{C} 1 \mathrm{~s}$ 


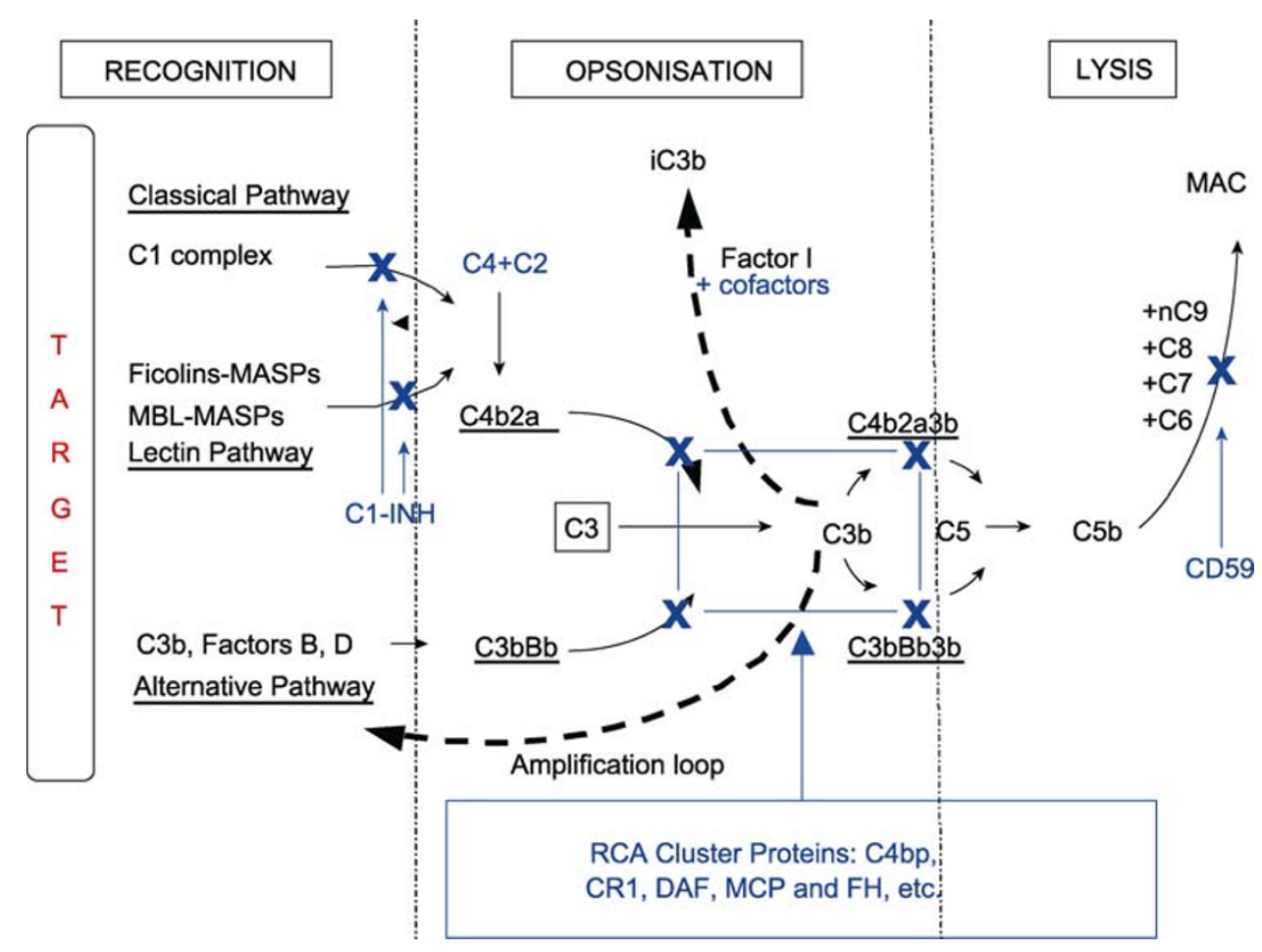

Figure 1. The complement activation pathways. The sequence of classical pathway activation is shown on the top of the figure: $\mathrm{C} 1 \mathrm{q}$ binds to the surface (top left), activating $\mathrm{C} 1 \mathrm{r}$ then $\mathrm{C} 1 \mathrm{~s}$, which then cleaves $\mathrm{C} 4$ and $\mathrm{C} 2$. The C4b2a complex (C3 convertase) forms on the bacterial surface and cleaves C3. One C3b molecule binds to C4b2a and forms a binding site for C5. C5 is cleaved and the C5b6789 complex (MAC) assembles and causes membrane damage. In the lectin pathway, MBL or a ficolin binds directly to a bacterial surface and MASP2 is activated. This protein then cleaves C4 and C2, after which the pathway follows the same sequence as the classical pathway. The alternative pathway is shown at the bottom left. C3b (derived from the classical or lectin pathway, or by activation by $\mathrm{C} 3(\mathrm{H} 2 \mathrm{O}) \mathrm{Bb}$ ) binds to the surface and binds Factor $\mathrm{B}$, which is activated by Factor $\mathrm{D}$, forming the $\mathrm{C} 3$ convertase $\mathrm{C} 3 \mathrm{bBb}$. More $\mathrm{C} 3$ is cleaved by $\mathrm{C} 3 \mathrm{bBb}$, followed by $\mathrm{C} 5$ activation and MAC assembly. The right panel shows the host cell and its mechanisms for protection against complement attack. CD59 binds to the C5b678 complex and prevents binding of C9. The regulators of complement activation (RCA) such as C4bp, CR1, MCP, and DAF destabilise the C3 and C5 convertases or inhibit their formation. Soluble regulators like $\mathrm{C} 1-\mathrm{INH}$ and Factor $\mathrm{H}$, which may temporarily be bound to the host cell membrane, may also regulate convertase formation.

cleaves complement proteins $\mathrm{C} 4$ and $\mathrm{C} 2$, forming complex protease C4b2a (C3 convertase), which cleaves C3 to C3a and C3b. Activated C3 (C3b) either binds to the targets and opsonises them to promote clearance by phagocytosis (Law and Reid, 1995) or binds to C3 convertases to form C5 convertases (Fig. 1; C4b2a3b (C5 convertase of classical and lectin pathways) and $\mathrm{C} 3 \mathrm{bBb} 3 \mathrm{~b}$ ( $\mathrm{C} 5$ convertase of alternative pathway)). In the terminal pathway, $\mathrm{C} 5$ cleavage ( $\mathrm{C} 5 \mathrm{a}$ and $\mathrm{C} 5 \mathrm{~b})$ by $\mathrm{C} 5$ convertases initiates the assembly of the membrane attack complex (MAC), which is composed of complement proteins C5b, C6, C7, C8, and C9(n) (Fig. 1). Insertion of MAC into lipid bilayers causes lysis of a target cell. Although the main function of the classical pathway is housekeeping via host waste disposal, it can be activated by some viruses and gram-positive and -negative bacteria (Sim and Malhotra, 1994; Butko et al., 1999).

The lectin pathway is initiated by complexes of pattern recognition molecules MBL or $\mathrm{L}-, \mathrm{H}-$, and $\mathrm{M}$ - ficolins with MBL-associated serine proteases (MASPs) (Petersen et al., 2001; Endo et al., 2006). The MBL or any of the ficolins binds to carbohydrate structures presented by a wide range of pathogens and mediate complement activation via activation of MASP-2. MASP-2 cleaves and activates complement proteins $\mathrm{C} 2$ and $\mathrm{C} 4$, thereby generating the $\mathrm{C} 3$ convertase C4b2a (Vorup-Jensen et al., 2000). From this point, the complement cascade is identical to that of the classical pathway (Fig. 1). The lectin pathway via MBL has both antibody-dependent and antibody-independent modes of activation. $\mathrm{H}$ and $\mathrm{L}$ ficolins have been shown to bind to a range of bacterial species (Krarup et al., 2005). M-ficolin is a cell-surface protein that has not been widely studied yet.

The deposition of C3b on a complement activator can trigger the alternative pathway of complement activation by binding to Factor $\mathrm{B}$ (a homologue of the classical pathway $\mathrm{C} 2$ ) 
and forming a C3bFB complex. This complex is cleaved by protease factor $D$ to form an alternative $C 3$ convertase (C3bBb), which cleaves more C3 (Fig. 1). In this manner, the alternative pathway acts as an amplifier that increases the covalent deposition of $\mathrm{C} 3 \mathrm{~b}$ on the target. Once the alternative pathway has been activated, the $\mathrm{C} 5$ convertase (C3bBbC3b) of this pathway is formed by the binding of an activated $\mathrm{C} 3 \mathrm{~b}$ to the target surface-bound $\mathrm{C} 3 \mathrm{bBb}$. The formation of $\mathrm{C} 5$ convertase leads to the activation of the terminal pathway and the assembly of MAC. The alternative pathway is activated by lgG immune complexes or by a wide range of bacteria, viruses, yeasts, and protozoans (Sim and Malhotra, 1994; Law and Reid, 1995). Small bioactive peptides called anaphylotoxins (e.g. C3a, C4a, and C5a) released from the cleavage of $\mathrm{C} 3, \mathrm{C} 4$, and $\mathrm{C} 5$ possess vasoactive properties. $\mathrm{C} 5 \mathrm{a}$ is also a chemotactic factor for neutrophils. In addition, $\mathrm{C} 3 \mathrm{a}$ and $\mathrm{C} 5 \mathrm{a}$ bind to $\mathrm{C} 3 \mathrm{aR}$ and $\mathrm{C} 5 \mathrm{aR}$ receptors of $\mathrm{T}$ lymphocytes and regulate their activation (Karp et al., 1996).

However, if C3b is deposited on a host cell, it is rapidly inactivated by cell-surface regulators of complement activation (RCA) such as complement receptor type 1 (CR1), decay-accelerating factor (DAF), and membrane cofactor protein (MCP) (Fig. 1). The other regulatory proteins, such as factor $\mathrm{H}$, factor $\mathrm{I}$, and $\mathrm{C} 4$ binding protein, also down-regulate complement activation (Sim et al., 2008). CUB and Sushi multiple domains 1 (CSMD1), CSMD2, and CSMD3 have been proposed to have a role in regulating complement activation and inflammation in the developing CNS (Nagase et al., 2001; Kraus et al., 2006).

C4b, C3b, iC3b, C3dg, and C3d bind to CR1 and complement receptor type 2 (CR2) on B lymphocytes and enhance antibody response and long-term memory of B-cells. Activation of CR1 and CR2 on the surface of follicular dendritic cells by immune complexes bound to $\mathrm{C} 3 \mathrm{~b}$ and $\mathrm{C} 4 \mathrm{~b}$ are essential for effective recall of an immune response (Carroll, 2004). There are two other complement receptors of interest: CR3 (CD11b/CD18) and CR4 (CD11c/CD18), which bind C3. CR3 also has affinity to C5a (Gerard and Gerard, 1991). CR3 and CR4 expressed on neutrophils and macrophages recognise and bind iC3b-opsonised targets, thus promoting and enhancing their phagocytosis. CR3 on membranes of other immune cells (e.g. T-cells and follicular dendritic cells) are possibly involved in the regulation of their functions. CD93 (phagocytic $\mathrm{C} 1 \mathrm{q}$ receptor) is another complement receptor that enhances phagocytosis and is controversially suggested to interact with C1q-sensitised targets (Tarr and Eggleton, 2005).

Since 1968, when the first complement genetic polymorphism for the C3 component was discovered (Alper and Propp, 1968; Azen and Smithis, 1968), stunning progress has been made in determining the genetic features of the complement system. At present, more than 45 genes that encode the proteins of complement or their isotypes and subunits, receptors, and regulators have been discovered (Table 1; updated from Schneider and Wurzner, 1999). These genes are distributed in different chromosomes, with only a few chromosomes not containing genes encoding proteins of the complement system (Table 1). Nineteen genes comprise three significant complement gene clusters in the human genome: (i) the regulators of complement activation (RCA) on chromosome 1, (ii) the gene cluster of MAC on chromosome 5, and (iii) the HLA class III cluster of early complement component genes on chromosome 6 (Table 1). Complement component deficiencies can occur due to many reasons, including single nucleotide polymorphisms (SNPs) and gene partial deletion and insertion. In addition, more than one genetic polymorphism can cause the deficiency of certain components. Clinically significant deficiencies of some components do not always coincide with protein deficiencies, but rather with their inability to execute corresponding functions. For instance, MBL B, C, and D variants may exist as low order oligomers and fail to activate the complement cascade (Heitzeneder et al., 2012). The MASP-2 $120 \mathrm{G}$ variant cannot associate with MBL and activate the complement (Stengaard-Pedersen et al., 2003)).

Deficiency of a component of any of the activation pathways that cannot be compensated for by the complement via a by-pass mechanism may lead to inappropriate activation of the system, impaired host defence against certain pathogens, and, in case of the classical pathway, increased susceptibility to autoimmune diseases. On the other hand, deficiency of an irreplaceable regulator can cause uncontrolled hyper-activation of the complement, thus inducing self-attack and host tissue damage. For instance, the deficiency of Factor-H contributes to age-related macular degeneration (AMD; Skerka et al., 2007). Deficiencies of complement receptors, depending on their involvement in the immune signalling circuit, may affect the complement functions of housekeeping, bridging of innate and adaptive immune systems, and promotion of cellular response.

This mini-review aims to provide an overview of current literature on the genetic load of complement component deficiencies and their associations with human diseases. The involvement of the specific components in complement system activation, regulation, and signalling was the primary consideration during data extraction. Furthermore, the effects of complement deficiencies on the main properties and functions of the entire complement system as a 'double edge sword' of innate immunity were analyzed. Updated genetic data in this review provide a background for further studies on complement disease association from the perspective of systems biology and systems genetics.

\section{EARLY COMPONENTS OF THE CLASSICAL AND ALTERNATIVE PATHWAYS}

The HLA class III cluster of early complement component genes on chromosome 6 (Table 1) has been a focus of in- 
Table 1 The chromosomal location of genes encoding complement proteins, inherited deficiency and disease associations

\begin{tabular}{|c|c|c|c|c|c|}
\hline Component (or subunit) & $\begin{array}{l}\text { Symbol of } \\
\text { gene }\end{array}$ & $\begin{array}{l}\text { Chromosomal } \\
\text { location }\end{array}$ & $\begin{array}{l}\text { Gene } \\
\text { cluster }\end{array}$ & $\begin{array}{l}\text { Disease association of the } \\
\text { homozygote deficiency }\end{array}$ & Genetic basis \\
\hline \multicolumn{6}{|l|}{ Activation components } \\
\hline C1q: A chain & C1QA & $1 \mathrm{p} 36.12$ & & $\begin{array}{l}\text { Immune complex diseases (ICD), SLE, } \\
\text { recurrent infections (RI) }\end{array}$ & SNP \\
\hline C1q: B chain & C1QB & $1 \mathrm{p} 36.12$ & & ICD, SLE, RI & SNP \\
\hline C1q: C chain & C1QC & $1 \mathrm{p} 36.11$ & & ICD, SLE, RI & SNP \\
\hline C1r & $C 1 R$ & $12 \mathrm{p} 13$ & & ICD, SLE, RI & - \\
\hline C1s & C1S & $12 \mathrm{p} 13$ & & ICD, SLE, RI & $\begin{array}{l}\text { Gene polymorphism (GP), } \\
\text { SNP, gene partial deletion }\end{array}$ \\
\hline $\mathrm{C} 2$ & $C 2$ & $6 p 21.3$ & C-MHC III & SLE, Neisserial infections (NI), RI & SNP, gene partial deletion \\
\hline Factor B & $C F B$ & $6 p 21.3$ & C-MHC III & $\begin{array}{l}\text { Homozygote: vary rare (fatal), } \\
\text { heterozygote: NI }\end{array}$ & - \\
\hline C4A (isotype) & C4A & $6 \mathrm{p} 21.3$ & C-MHC III & $\begin{array}{l}\text { ICD, RI, autoimmune disorders (e.g. } \\
\text { SLE, type } 1 \text { diabetes mellitus, } \\
\text { autoimmune hepatitis, scleroderma) }\end{array}$ & $\begin{array}{l}\text { Gene deletion, gene } \\
\text { conversion, non-expression } \\
\text { due to insertion }\end{array}$ \\
\hline C4B (isotype) & $C 4 B$ & $6 \mathrm{p} 21.3$ & C-MHC III & $\begin{array}{l}\mathrm{RI} \text {, autoimmune disorders (e.g. primary } \\
\text { biliary cirrhosis) }\end{array}$ & $\begin{array}{l}\text { Gene deletion, gene } \\
\text { conversion, non-expression } \\
\text { due to insertion }\end{array}$ \\
\hline C3 & C3 & 19p13.3-p13.2 & & $\begin{array}{l}\text { Severe disseminated pyogenic } \\
\text { infections, ICD }\end{array}$ & SNP, gene partial deletion \\
\hline C5 & C5 & $9 q 33-q 34$ & & Recurrent $\mathrm{NI}$ & SNP \\
\hline $\mathrm{C} 6$ & C6 & $5 p 13$ & MAC & Recurrent NI & GP and SNP \\
\hline $\mathrm{C} 7$ & $C 7$ & $5 p 13$ & MAC & Recurrent NI & SNP, gene partial deletion \\
\hline C8: $\alpha$-chain & C8A & $1 \mathrm{p} 32$ & & Recurrent NI & SNP \\
\hline C8: $\beta$-chain & $C 8 B$ & $1 \mathrm{p} 32$ & & Recurrent NI & SNP \\
\hline C8: $\gamma$-chain & C8G & $9 q 34.3$ & & Recurrent NI & SNP \\
\hline $\mathrm{C9}$ & C9 & $5 p 14-p 12$ & MAC & Recurrent NI & SNP \\
\hline Factor D & $C F D$ & $19 p 13.3$ & & Recurrent NI & - \\
\hline Properdin & CFP & Xp11.3-p11.23 & & $\begin{array}{l}N . \text { meningitidis, fulminant infections, } \\
\text { meningococcal sepsis }\end{array}$ & GP and SNP \\
\hline MBL & $M B L 2$ & 10q11.2-q21 & & $\mathrm{RI}$ in children & GP and SNP \\
\hline MASP-1 & MASP1 & $3 q 27-q 28$ & & - & - \\
\hline MASP-2 & MASP2 & 1p36.3-p36.2 & & - & GP and SNP \\
\hline M-ficolin & FCN1 & $9 q 34$ & & - & - \\
\hline L-ficolin & FCN2 & $9 q 34.3$ & & - & - \\
\hline $\mathrm{H}$-ficolin & FCN3 & $1 \mathrm{p} 36.11$ & & RI & Frameshift mutation \\
\hline \multicolumn{6}{|l|}{ Regulators and receptors } \\
\hline C4 binding protein: $\alpha$ chain & C4BPA & $1 q 32$ & RCA & - & - \\
\hline C4 binding protein: $\beta$ chain & $C 4 B P B$ & $1 q 32$ & RCA & - & - \\
\hline CR1 (CD35) & CR1 & $1 q 32$ & RCA & ICD, glomerulonephritis & SNP \\
\hline CR2 (CD21) & CR2 & $1 q 32$ & RCA & - & - \\
\hline $\begin{array}{l}\text { CD55 (decay accelerating } \\
\text { factor, DAF) }\end{array}$ & $C D 55$ & $1 q 32$ & RCA & Inab blood group phenotype & Gene partial deletion \\
\hline
\end{tabular}




\begin{tabular}{|c|c|c|c|c|c|}
\hline Component (or subunit) & $\begin{array}{l}\text { Symbol of } \\
\text { gene }\end{array}$ & $\begin{array}{l}\text { Chromosomal } \\
\text { location }\end{array}$ & $\begin{array}{l}\text { Gene } \\
\text { cluster }\end{array}$ & $\begin{array}{l}\text { Disease association of the } \\
\text { homozygote deficiency }\end{array}$ & Genetic basis \\
\hline $\begin{array}{l}\text { CD46 (membrane cofactor } \\
\text { protein, MCP) }\end{array}$ & $C D 46$ & $1 q 32$ & RCA & $\begin{array}{l}\text { Atypical hemolytic uremic syndrome } \\
\text { (HUS), }\end{array}$ & \\
\hline Factor $\mathrm{H}$ & $\mathrm{CFH}$ & $1 q 32$ & $\mathrm{RCA}$ & $\begin{array}{l}\mathrm{NI} \text {, glomerulonephritis, HUS, thrombotic } \\
\text { thrombocytopenic purpura, age-related } \\
\text { macular degeneration (AMD) }\end{array}$ & SNP, gene partial deletion \\
\hline $\begin{array}{l}\text { Complement Factor } \\
\text { H-Related } 1\end{array}$ & CFHR1 & $1 q 32$ & $\mathrm{RCA}$ & Atypical HUS; protective for AMD & Deletion \\
\hline $\begin{array}{l}\text { Complement Factor } \\
\text { H-Related } 2\end{array}$ & CFHR2 & $1 \mathrm{q} 31.3$ & RCA & - & - \\
\hline $\begin{array}{l}\text { Complement Factor } \\
\text { H-Related } 3\end{array}$ & CFHR3 & $1 q 32$ & $\mathrm{RCA}$ & Atypical HUS; protective for AMD & Deletion \\
\hline $\begin{array}{l}\text { Complement Factor } \\
\text { H-Related } 4\end{array}$ & CFHR4 & $1 q 32$ & RCA & - & - \\
\hline $\begin{array}{l}\text { Complement Factor } \\
\text { H-Related } 5\end{array}$ & CFHR5 & $1 \mathrm{q} 31.3$ & $\mathrm{RCA}$ & - & - \\
\hline $\begin{array}{l}\text { CSMD2 (CUB and Sushi } \\
\text { multiple domains 2) }\end{array}$ & CSMD2 & $1 \mathrm{p} 35.1-34.3$ & & - & - \\
\hline $\begin{array}{l}\text { CSMD1 (CUB and Sushi } \\
\text { multiple domains 1) }\end{array}$ & CSMD1 & $8 p 23.2$ & & - & - \\
\hline $\begin{array}{l}\text { CSMD3 (CUB and Sushi } \\
\text { multiple domains } 3 \text { ) }\end{array}$ & CSMD3 & $8 p 23.3$ & & - & - \\
\hline $\begin{array}{l}\text { CD59 (membrane inhibitor } \\
\text { of reactive lysis, MIRL) }\end{array}$ & CD59 & $11 \mathrm{p} 13$ & & Paroxysmal nocturnal hemoglobinuria & \\
\hline Factor I & $\mathrm{CFI}$ & $4 q 25$ & & $\mathrm{RI}$ & SNP \\
\hline C1 Inhibitor & SERPING1 & $11 q 12-q 13.1$ & & Angioedema & SNP, gene partial deletion \\
\hline MASP-3 & MASP1 & $3 q 27-q 28$ & & - & - \\
\hline MAp44 & MASP1 & $3 q 27-q 28$ & & - & - \\
\hline MAp19 & MASP2 & $1 p 36.3-p 36.2$ & & - & - \\
\hline $\begin{array}{l}\text { CR3 (CD11b/CD18) a-chain } \\
=\text { aM-Integrin } \\
\text { (CR3A,CD11b); }\end{array}$ & ITGAM & $16 \mathrm{p} 11.2$ & & Recurrent bacterial skin infections & - \\
\hline $\begin{array}{l}\beta \text {-chain }=\beta_{2} \text {-Integrin } \\
\text { (Leucocyte adhesion } \\
\text { molecule, CD18) }\end{array}$ & ITGB2 & $21 q 22.3$ & & Leucocyte adhesion deficiency & SNP, gene partial deletion \\
\hline $\begin{array}{l}\text { CR4 (CD11c/CD18) } \alpha \text {-chain } \\
=\alpha X \text {-Integrin }(C D 11 \mathrm{c})\end{array}$ & ITGAX & $16 \mathrm{p} 11.2$ & & - & - \\
\hline C5aR1 (C5a receptor 1) & C5AR1 & $19 q 13.3-q 13.4$ & & - & - \\
\hline C3aR1 (C3a receptor 1) & C3AR1 & $12 \mathrm{p} 13.31$ & & - & - \\
\hline CD93 & $C D 93$ & 20p11.21 & & - & - \\
\hline
\end{tabular}

terest for a long time due to the complex disease associations of human HLA. In this cluster, two genes encoding human complement $\mathrm{C} 4$ protein $(\mathrm{C} 4 \mathrm{~A}$ and $\mathrm{C} 4 \mathrm{~B})$ together with the serine/threonine nuclear kinase gene RP, the steroid 21-hydroxylase CYP21, and the extracellular matrix protein tenascin X (TNX) form a genetic unit: the RP-C4-CYP21-TNX (RCCX) module (Yang et al., 1999). The presence of a duplicated RCCX module has given rise to a complex structural polymorphism involving segmental deletions and duplications of the isotypic $\mathrm{C} 4 \mathrm{~A}$ and $\mathrm{C} 4 \mathrm{~B}$ genes, which is the major cause of genetic C4 deficiency. Moreover, C4 deficiency may also occur due to gene conversion ( $\mathrm{C} 4 \mathrm{~A}$ to $\mathrm{C} 4 \mathrm{~B}$ or $\mathrm{C} 4 \mathrm{~B}$ to $\mathrm{C} 4 \mathrm{~A}$ ) and point mutations resulting in pseudogenes. This is further complicated by the fact that the number of $\mathrm{C} 4$ genes within a genotype varies from 2 to 8 (Blanchong et al., 2001). Three quarters of the $\mathrm{C} 4$ genes in Caucasians have an endogenous retrovirus (HERV-K (C4)) in intron nine, which are designated as C4 long genes; those without insertions are called short genes (Schneider et al., 2001). Many infectious and autoimmune diseases are associated with complete or partial deficiency of C4A and/or C4B (Hohler et al., 2002; Yu et al., 2003). However, the strong linkage disequilibrium of HLA 
haplotypes makes it difficult to identify particular candidate genes.

Two genes encoding serine proteases of the classical and alternative pathways ( $\mathrm{C} 2$ and factor $\mathrm{B}$, respectively) are situated in the same region (Table 1). In European populations, homozygous C2 deficiency is one of the common inherited complement deficiencies (Pickering et al., 2000). Many of these individuals ( $>60 \%$ ) do not suffer from any apparent disease, probably due to the compensatory involvement of factor $B$ in the activation of the complement via C2 bypass mechanism (Laich and Sim, 2001). Almost 40\% of individuals with $\mathrm{C} 2$ deficiency develop systemic autoimmune disease (Agnello et al., 1972; Day et al., 1973; Sjoholm et al., 2006). For instance, systemic lupus erythematosis (SLE) is a disease that presents with facial erythema and oral or nasopharyngeal ulceration. The association of $\mathrm{C} 1, \mathrm{C} 2$, or C4 deficiency with this disease suggests that these components have some role in the clearance of immune complexes (Law and Reid, 1995). Sub-epithelial IC deposits are part of the histopathology of SLE. In the case of SLE and IC disorders, C4 is exclusively correlated with the deficiency of the C4A isotype, even at the level of heterozygous deficiency (Yang et al., 2004). On the other hand, C4 deficiency is also associated with a number of autoimmune disorders that are not characterised by abnormalities of IC clearance (e.g. type 1 diabetes mellitus, primary biliary cirrhosis). Recent studies suggest an association between C4B heterozygote deficiency and increased risk for schizophrenia (Mayilyan et al., 2007; Mayilyan and Weinberger, 2008; Mayilyan et al., 2012). Another potential problem of individuals with $\mathrm{C} 1, \mathrm{C} 2$, or $\mathrm{C} 4$ deficiencies is deep, recurrent pyogenic infections.

Homozygous deficiency of factor B has not been described, leading to suggestions that this deficiency is probably fatal (Law and Reid, 1995). Deficiency of other genes encoding alternative pathway components, such as properdin and factor $\mathrm{D}$, demonstrated the importance of this pathway in battling neisserial (meningococcal) infections (Sjoholm et al., 2002, 2006). Complete C3 deficiency caused serious infections in the 27 described cases, suggesting that this component is crucial for complement functional interplay with innate immunity. Individuals with C3 deficiency suffer severe disseminated pyogenic infections (Reis et al., 2006).

\section{COMPONENTS OF THE LECTIN PATHWAY}

A large number of studies to determine the relationship between MBL levels and various diseases have been carried out (Sim et al., 2006). In 1989, Super et al. discovered that many children with recurrent infections were MBL-deficient. Subsequently, MBL deficiency due to $M B L-2$ gene exon 1 mutations ( $B, C$, and $D$ variants) and three other SNPs in promoter region $(H / L, Y / X$, and $P / Q)$ were observed in children with a syndrome of frequent infections and opsonin deficiency (Sumiya et al., 1991; Summerfield et al., 1997, Turner and Hamvas, 2000). Since the first description by Turner's group (Super et al. 1989), MBL deficiency has been found in association with different autoimmune (e.g. rheumatoid arthritis (Graudal et al., 1998, Martiny et al., 2012) and SLE (Davies et al., 1995; Sullivan et al., 1996; Glesse et al., 2011)) and infectious disorders (e.g. lung infection, septicaemia, and meningitis (Garred et al., 1995; Summerfield et al., 1997; reviewed in Turner, 2003; Sim et al., 2006; Heitzeneder et al., 2012)). However, the high frequency ( $5 \%$ worldwide) of MBL homozygous deficiency in normal individuals indicates that the MBL-mediated complement activation pathway may be of considerable importance for opsonisation in individuals with immature or deficient immune systems. Moreover, Dahl et al. (2004) reported that MBL deficiency is not a major risk factor for morbidity or death in the Caucasian adult population.

In the Danish population, one person with complete MASP-2 deficiency due to a missense SNP in the gene $M A S P 2$, presenting with recurrent pyogenic infections, has been found (Stengaard-Pedersen et al., 2003). Initial analysis indicated that allele frequency for the mutation is $5.5 \%$ in the Caucasian population and thus might be common. A previous study revealed the low clinical importance of MASP-2 deficiency (Garcia-Laorden et al., 2008). Unlike $\mathrm{L}-$ and $\mathrm{M}$ - ficolins, a frame-shift mutation in the FCN3 gene was found to be associated with $\mathrm{H}$-ficolin protein deficiency. A patient who was homozygous for this mutation had recurrent infections (Munthe-Fog et al., 2009). Along with MASP1 (MASP-1/3 and MAp44 proteins) and MASP2 (MASP-2 and MAp19 proteins), a number of SNPs have been described for FCNs (Garred et al., 2010; Degn et al., 2011). However, the importance of ficolins in general and the genetic variations in $F C N$ genes in particular remain largely unknown.

\section{COMPONENTS OF THE TERMINAL PATHWAY}

Deficiencies of MAC components (C5, C6, C7, C8, and C9) are associated with recurrent invasive infections caused by Neisseria meningitidis and $N$. gonorrhoeae, indicating that the serum bactericidal function of MAC is important in the defence against neisserial infections (Figueroa and Densen, 1991). These organisms either possess a capsular polysaccharide, which precludes successful phagocytosis, or can invade cells and propagate intracellularly. In either case, phagocytosis is ineffective. Fortunately, these organisms are susceptible to the serum bactericidal effect of MAC. Rarely, SLE-like diseases have been associated with these deficiencies. Since $\mathrm{C} 8$ is encoded on three different genes, there are differences in the type of $\mathrm{C} 8$ deficiencies (C8 $\beta$ in Caucasians; $\mathrm{C} 8 \alpha$ or $\mathrm{C} 8 \mathrm{y}$ in Asian and African populations) (Sjoholm et al., 2002).

The description of murine strains deficient in complement 
component $\mathrm{C} 5$ was followed by the recognition of a variety of naturally-occurring complement component deficiencies, many of which have been characterised at the molecular level, in a range of animal species. The use of such species in inflammatory and infectious experimental models has led to significant progress in understanding the role of specific complement factors and pathways in disease pathogenesis (Linton, 2001). Further investigations on such naturally deficient strains, together with results derived from studies in knockout animals and case studies of human individuals with complete deficiency of any complement component, will allow us to expand our understanding of the role of the complement system in innate immunity and in human diseases. The results obtained may also have potential significant implications for the treatment of these diseases.

\section{COMPLEMENT REGULATORS AND RECEPTORS}

Genes of the complement regulators, including C4-binding protein ( $\alpha$ and $\beta$ chains), CR1, CR2, DAF, MCP, and factor $\mathrm{H}$ and genes of the complement factor $\mathrm{H}$-related (1-5) proteins compose the RCA cluster. The RCA gene region products are also known as a "C $3 \mathrm{~b}$ binding protein family" (Reid et al., 1986). All three complement pathways lead to the formation of C3b, whose fate depends on the presence or absence of regulatory proteins. The main function of regulatory proteins is to defend host cells against over-activation of the complement system by inactivation of C3b, either fluid phase or covalently bound to the surface of cells. In the absence of RCA gene products, the complements can lead to the formation of both chemo-attractant C5a and MAC, thus damaging host cells. The presence of RCA gene cluster products leads to better opsonisation through the formation of a $\mathrm{C} 3$ fragment called Opsonisation iC $3 b, B$-cell enhancement by the formation of C3dg and its binding to the RCA cluster product CR2 (complement receptor 2), and self-protection (e.g. MCP: $\mathrm{C} 3 \mathrm{~b} / \mathrm{C} 4 \mathrm{~b}$ inactivation and DAF: $\mathrm{C} 3 \mathrm{bBb}$ dissociation). Genetic deficiency in factor I, which allows uncontrolled activation of alternative pathway and depression of the levels of both factor B and C3 components, has low frequency (Reis et al., 2006). Subjects with insufficient factor $I$, as in the case of factor $\mathrm{H}$ deficiency, generally present with bacterial infection due to the low opsonic activity via the alternative pathway because of the depletion of C3 (Reis et al., 2006). Deficiencies in regulator proteins anchored in host cell membranes via a glycophosphatidyl inositol (GPI) group), such as DAF and CD59, elevate sensitivity of erythrocytes to complement lysis. Individuals with a deficiency of these membrane-associated regulators, most frequently due to a deficiency of GPI anchor formation, are prone to paroxysmal nocturnal hemoglobinuria (PNH) (Takeda et al., 1993). PNH is characterised by intravascular destruction of erythrocytes and results in oxygen insufficiency and hemoglobin excretion by the kidneys. DAF deficiency is less clinically obvious, since its functions are also mediated by other molecules (e.g. CR1, factor $\mathrm{H}$ ). Therefore, it has been suggested that CD59 is more important in preventing PNH than DAF. CR1 deficiency has been associated with mesangiocapillary glomerulonephritis (Ohi et al., 1986) and $\mathrm{H}$ factor deficiency has been strongly associated with hemolytic uremic syndrome (Imbasciati et al., 2003). The deficiency of another complement regulatory protein $(\mathrm{C} 1-\mathrm{INH})$ can result in hereditary angioedema, whose symptoms include swollen mucosae, particularly the lips (Bracho, 2005). Angioedema of the oropharynx leads to life-threatening airway obstructions. C1-INH deficiency has been suggested to be associated with increased vascular permeability, thus oedema (Bracho, 2005).

Current knowledge state that CR3 and CR4 deficiencies occur simultaneously in patients with leukocyte adhesion deficiency (LAD) type 1 due to genetic defects in the CD18 ( $\beta$-subunit of both complement receptors) gene, ITGB2 (Springer et al., 1984, 1986; Roos et al., 2002; Bernard Cher et al., 2012). The lack of memory/effector CD8+ T cells and neutrophils in these patients result in reduced phagocytic response to bacteria and yeast. Most clinical features are probably the result of CR3 deficiency of neutrophils and monocytes (Springer et al., 1984, 1986). The reduced ability of such neutrophils to adhere to various substances, including complement-derived chemo-attractants (e.g. C5a (Gerard and Gerard, 1991)), leads to defects in neutrophil migration into sites of infection.

\section{CONCLUSION}

Knowledge gained from conventional genetic deficiency of complement components helped in the functional characterisation of many proteins of this important cascade system. Genetic deficiencies of the early components of the classical pathway (C1-C4) are associated with autoimmune disease due to failure of the pathway to develop a normal humoral response and to perform effective housecleaning (e.g. removal of immune complexes, apoptotic materials, and necrotic debris). These reports emphasise that the removal of endogenous debris requires a highly tactful approach, in which mechanisms downstream of $\mathrm{C} 3$, such as the inflammatory $\mathrm{C} 5 \mathrm{a}-\mathrm{C} 5 \mathrm{aR}$ axis and MAC assembly, should be avoided (Ricklin et al., 2010).

Deficiencies of early components of the lectin (MBL) and alternative (factor $D$, properdin) pathways increase susceptibility to infections and their recurrence due to the lack of complements to recognise and opsonise foreign invaders. The lack of information on homozygous deficiency of factor $B$ emphasises the importance of this component and the major role of the alternative pathway in the activation of the entire complement system through the amplification loop and its involvement in immune response (Law and Reid, 1995). The clinical manifestation of deficiencies of terminal pathway components (C3-C9) is similar to those of lectin and 
alternative pathways components, except that the increased susceptibility to infection is due to the failure of the complement system to lyse microbial cells. Depending on the regulatory or signalling steps they are involved in, the consequences of deficiencies in complement regulators and receptors vary. Thus, the diverse range of complement homozygote deficiencies highlights the multi-faceted involvement of the complement system in innate and adaptive immunity and beyond.

It is clear that the heritability of complement systemassociated diseases is not limited by homozygote and/or heterozygote deficiencies of complement components. Less crucial polymorphisms of these genes have been reported in association with some autoimmune and infectious disorders. Genome-wide association studies and sequencing and targeting investigations have made phenomenal contributions to our understanding of common heritability diseases. However, gene-environment interaction studies of most diseases are still in their infancy and the contribution of such interactions to heritability remain unknown (Cortes and Brown, 2011). From this perspective, the clinical significance of the known and unknown genetic variants of complement components (e.g. SNPs and gene copy number variations) and their epigenetic effects, gene-gene interactions, and gene-environment interactions must be addressed in the future. Therefore, the updated information on more than 45 genes presented in Table 1 can be useful for disease association studies of the complement system from aspects of systems biology and systems genetics.

\section{ACKNOWLEDGEMENTS}

KRM is grateful to Dr. Robert B. Sim from the MRC Immunochemistry Unit, Oxford University (Oxford, UK) for valuable discussions. This work was supported by the DAAD fellowship (No. A/04/05511) and ANSEF (No. NS-molbio-2645) grant.

\section{ABBREVIATIONS}

AMD, age-related macular degeneration; CUB, C1r/s Uegf Bone morphogenetic protein-1 (module); CR1, complement receptor type 1; CR2, complement receptor type 2; CR3, complement receptor type 3; CR4, complement receptor type 4; DAF, decay accelerating factor; GP, gene polymorphism; HLA, human leukocyte antigen system; HUS, hemolytic uremic syndrome; IC, immune complexes; ICD, immune complex diseases; LAD, leucocyte adhesion deficiency; MAC, membrane attack complex; MAp19, mannan-binding lectinassociated plasma protein of $19 \mathrm{kDa}$; Map44, mannan-binding lectin-associated plasma protein of $44 \mathrm{kDa}$; MASP, MBL-associated serine protease; MBL, mannan-binding lectin; MCP, membrane cofactor protein; NI, Neisserial infections; PAMP, pathogen-associated molecular patterns; RCA, regulators of complement activation; RI, recurrent infections; SLE, systemic lupus erythematosus; SNP, single nucleotide polymorphism

\section{REFERENCES}

Agnello, V., De Bracco, M.M., and Kunkel, H.G. (1972). Hereditary C2 deficiency with some manifestations of systemic lupus erythematosus. J Immunol 108, 837-840.

Alper, C.A., and Propp, R.P. (1968). Genetic polymorphism of the third component of human complement (C'3). J Clin Invest 47, 2181-2191.

Azen, E.A., and Smithis, O. (1968). Genetic polymorphism of C'3(beta1C-globulin) in human serum. Science 162, 905-907.

Bernard Cher, T.H., Chan, H.S., Klein, G.F., Jabkowski, J., Schadenböck-Kranzl, G., Zach, O., Roca, X., and Law, S.K. (2011). A novel 30 splice-site mutation and a novel gross deletion in leukocyte adhesion deficiency (LAD)-1. Biochem Biophys Res Commun 404, 1099-1104.

Blanchong, C.A., Chung, E.K., Rupert, K.L., Yang, Y., Yang, Z., Zhou, B., Moulds, J.M., and Yu, C.Y. (2001). Genetic, structural and functional diversities of human complement components $\mathrm{C} 4 \mathrm{~A}$ and C4B and their mouse homologues, SIp and C4. Int Immunopharmacol 1, 365-392.

Bracho, F.A. (2005). Hereditary angioedema. Curr Opin Hematol 12, 493-498.

Butko, P., Nicholson-Weller, A., and Wessels, M.R. (1999). Role of complement component $\mathrm{C} 1 \mathrm{q}$ in the $\mathrm{lgG}$-independent opsonophagocytosis of group B streptococcus. J Immunol 163, 2761-2768.

Carroll, M.C. (2004). The complement system in regulation of adaptive immunity. Nat Immunol 5, 981-986.

Cortes, A., and Brown, M.A. (2011). Promise and pitfalls of the Immunochip. Arthritis Res Ther 13, 101.

Dahl, M., Tybjaerg-Hansen, A., Schnohr, P., and Nordestgaard, B.G. (2004). A population-based study of morbidity and mortality in mannose-binding lectin deficiency. J Exp Med 199, 1391-1399.

Davies, E.J., The, L.S., Ordi-Ros, J., Snowden, N., Hillarby, M.C., Hajeer, A., Donn, R., Perez-Pemen, P., Vilardell-Tarres, M., and Ollier, W.E. (1997). A dysfunctional allele of the mannose binding protein gene associates with systemic lupus erythematosus in a Spanish population. J Rheumatol 24, 485-488.

Day, N.K., Geiger, H., McLean, R., Michael, A., and Good, R.A. (1973). C2 deficiency. Development of lupus erythematosus. J Clin Invest 52, 1601-1607.

Degn, S.E., Jensenius, J.C., and Thiel, S. (2011) Disease-causing mutations in genes of the complement system. Am J Hum Genet 88, 689-705.

Endo, Y., Takahashi, M., and Fujita, T. (2006). Lectin complement system and pattern recognition. Immunobiol 211, 283.

Figueroa, J.E., and Densen, P. (1991). Infectious diseases associated with complement deficiencies. Clin Microbiol Rev 4, 359-395.

Garcia-Laorden, M.I., Sole-Violan, J., Rodriguez de Castro, F., Aspa, J., Briones, M.L., Garcia-Saavedra, A., Rajas, O., Blanquer, J., Caballero-Hidalgo, A., Marcos-Ramos, J.A., et al. (2008). Mannose-binding lectin and mannose-binding lectin-associated serine protease 2 in susceptibility, severity, and outcome of pneumonia in adults. Allergy Clin Immunol 122, 368-374.

Garred, P., Honoré, C., Ma, Y.J., Rørvig, S., Cowland, J., Borregaard, N., and Hummelshøj, T. (2010) The genetics of ficolins. J Innate 
Immun 2, 3-16.

Garred, P., Madsen, H.O., Hofmann, B, and Svejgaard, A. (1995). Increased frequency of homozygosity of abnormal mannan-binding-protein alleles in patients with suspected immunodeficiency. Lancet 346, 941-943.

Gerard, N.P., and Gerard, C. (1991). The chemotactic receptor for human C5a anaphylatoxin. Nature 349, 614-617.

Glesse, N., Monticielo, O.A., Mattevi, V.S., Brenol, J.C., Xavier, R.M., da Silva, G.K., Dos Santos, B.P., Rucatti, G.G., and Chies, J.A. (2011). Association of mannose-binding lectin 2 gene polymorphic variants with susceptibility and clinical progression in systemic lupus erythematosus. Clin Exp Rheumatol 29, 983-990.

Graudal, N.A., Homann, C., Madsen, H.O., Svejgaard, A., Jurik, A.G., Graudal, H.K., and Garred, P. (1998). Mannan binding lectin in rheumatoid arthritis. A longitudinal study. J Rheumatol 25, 629-635.

Heitzeneder, S., Seidel, M., Förster-Waldl, E., and Heitger, A (2012). Mannan-binding lectin deficiency - Good news, bad news, doesn't matter? Clin Immunol 143, 22-38.

Hohler, T., Stradmann-Bellinghausen, B., Starke, R., Sanger, R., Victor, A., Rittner, C, and Schneider, P.M. (2002). C4A deficiency and nonresponse to hepatitis B vaccination. J Hepatol 37, 387-392.

Imbasciati, E., Bucci, R., Barbisoni, F., Borlandelli, S., Corradi, B., Cosci, P., Farina, M., and Mandolfo, S. (2003). Acute renal failure and thrombotic microangiopathy. G Ital Nefrol 20, 285-297.

Karp, C.L., Wysocka, M., Wahl, L.M., Ahearn, J.M., Cuomo, P.J., Sherry, B., Trinchieri, G., and Griffin, D.E. (1996). Mechanism of suppression of cell-mediated immunity by measles virus. Science 273, 228-231.

Krarup, A., Sorensen, U.B., Matsushita, M., Jensenius, J.C., and Thiel S. (2005). Effect of capsulation of opportunistic pathogenic bacteria on binding of the pattern recognition molecules mannan-binding lectin, L-ficolin, and H-ficolin. Infect Immun 73, 1052-1060.

Kraus, D.M., Elliott, G.S., Chute, H., Horan, T., Pfenninger K.H., Sanford, SD., Foster, S., Scully, S., Welcher, A.A., and Holers, V.M. (2006). CSMD1 is a novel multiple domain complementregulatory protein highly expressed in the central nervous system and epithelial tissues. J Immunol 176, 4419-4430.

Laich, A., and Sim, R.B. (2001). Cross-talk between the human complement classical and alternative pathways: evidence for a C4bBb 'hybrid' C3 convertase. Mol Immunol 38, 105.

Langer, H.F., Chung, K.J., Orlova, V.V., Choi, E.Y., Kaul, S., Kruhlak, M.J., Alatsatianos, M., Deangelis, R.A., Roche, P.A., Magotti, P., et al. (2010). Complement-mediated inhibition of neovascularization reveals a point of convergence between innate immunity and angiogenesis. Blood 116, 4395-4403.

Law, S.K.A., and Reid, K.B.M. (1995). Complement (Oxford: IRL Press at Oxford University Press).

Linton, S. (2001). Animal models of inherited complement deficiency. Mol Biotechnol 18, 135-148.

Martiny, F.L., Veit, T.D., Brenol, C.V., Brenol, J.C., Xavier, R.M., Bogo, M.R., and Chies, J.A. (2012). Mannose-binding lectin gene polymorphisms in Brazilian patients with rheumatoid arthritis. J Rheumatol 39, 6-9.

Mayilyan, K.R., Kang, Y.H., Dodds, A.W., and Sim, R.B. (2008).The complement system in innate immunity. In Innate Immunity of Plants, Animals and Humans (Series: Nucleic Acids and Molecular Biology, Vol. 21), H. Heine, ed. (Heidelberg: Springer), pp. 219-236.

Mayilyan, K.R., Schneider, P.M., Hartmann, A., Hähnel, P.S., Stradmann-Bellinghausen, B., Möller, H.J., Soghoyan, A.F., Rujescu, D., and Sim, R.B. (2012). Complement C4 genes in schizophrenia: a study using a new genotyping approach to RP-C4-CYP21-TNX unit screening (in press).

Mayilyan, K.R., and Weinberger, D.R. (2008). Involvement of the HLA genetic diversity in schizophrenia: supporting data and perspectives. ASHI Quarterly (The American Society of Histocompatibility and Immunogenetics) $32,74-80$.

Mayilyan, K.R., Weinberger, D.R., Wu, Y.L., Kolachana, B., McBride, K., and Yung, C.Y. (2007). Association of complement C4B gene deficiency with schizophrenia: studies of European American families and controls. Abstracts of XV World Congress on Psychiatric Genetics, 7-11 October, 2007, New York, NY, USA, $\mathrm{P} 109$.

Munthe-Fog, L., Hummelshøj, T., Honoré, C., Madsen, H.O., Permin, H., and Garred, P. (2009). Immunodeficiency associated with FCN3 mutation and ficolin-3 deficiency. N Engl J Med 360, 2637-2644.

Nagase, T., Kikuno, R., and Ohara, O. (2001). Prediction of the coding sequences of unidentified human genes. XXI. The complete sequences of 60 new cDNA clones from brain which code for large proteins. DNA Res 8, 179-187.

Ohi, H., Ikezawa, T., Watanabe, S., Seki, M., Mizutani, Y., Nawa, N., and Hatano, M. (1986). Two cases of mesangiocapillary glomerulonephritis with CR1 deficiency. Nephron 43, 307.

Petersen, S.V., Thiel, S., and Jensenius, J.C. (2001). The mannan-binding lectin pathway of complement activation: biology and disease association. Mol Immunol 38, 133-149.

Pickering, M.C., Botto, M., Taylor, P.R., Lachmann, P.J., and Walport, M.J. (2000). Systemic lupus erythematosus, complement deficiency, and apoptosis. Adv Immunol 76, 227-324.

Rahpeymai, Y., Hietala, M.A., Wilhelmsson, U., Fotheringham, A., Davies, I., Nilsson, A.K., Zwirner, J., Wetsel, R.A., Gerard, C., Pekny, M., et al. (2006). Complement: a novel factor in basal and ischemia-induced neurogenesis. EMBO J 25, 1364-1374.

Reid, K.B.M., Bentley, D.R., Campbell, R.D., Chung, L.P., Sim, R.B., Kristensen, T., and Tack, B.F. (1986). Complement-system proteins which interact with $\mathrm{C} 3 \mathrm{~B}$ or $\mathrm{C} 4 \mathrm{~B}-\mathrm{A}$ superfamily of structurally related proteins. Immunol Today 7, 230-234.

Reis, S.E., Falcao, D.A., and Isaac, L. (2006). Clinical aspects and molecular basis of primary deficiencies of complement component $\mathrm{C} 3$ and its regulatory proteins factor I and factor $\mathrm{H}$. Scand J Immunol 63, 155-168

Ricklin, D., Hajishengallis, G., Yang, K., and Lambris, J.D. (2010). Complement: a key system for immune surveillance and homeostasis. Nat Immunol 11, 785-797.

Roos, D., Meischl, C., de Boer, M., Simsek, S., Weening, R.S., Sanal, O., Tezcan, I., Güngör, T., and Law, S.K. (2002). Genetic analysis of patients with leukocyte adhesion deficiency: genomic sequencing reveals otherwise undetectable mutations. Exp Hematol 30, 252-261.

Schneider, P.M., Witzel-Schlömp, K., Rittner, C., and Zhang, L. 
(2001). The endogenous retroviral insertion in the human complement C4 gene modulates the expression of homologous genes by antisense inhibition. Immunogenetics 53, 1-9.

Schneider, P.M., and Wurzner, R. (1999).Complement genetics: biological implications of polymorphisms and deficiencies. Immunol Today 20, 2-5

Sim, R.B., and Malhotra, R. (1994). Interactions of carbohydrates and lectins with complement. Biochem Soc Trans 22, 106-111.

Sim, R.B., Clark, H., Hajela, K., and Mayilyan, K.R. (2006). Collectins and host defence. Novartis Found Symp 279, 170-181.

Sim, R.B., Moffatt, B.E., Shaw, J.M., and Ferluga J. (2008). Complement control proteins and receptors: from FH to CR4. In Molecular Aspects of Innate and Adaptive Immunity, K.B.M. Reid, and R.B. Sim, eds (Cambridge, UK: RSC Publishing), pp. 84-104.

Sjoholm, A.G. (2002). Deficiencies of mannan-binding lectin, the alternative pathway, and the late complement components. In Manual of Clinical Laboratory Immunology, 6th ed, N.R. Rose, R.G. Hamilton, B. Detrick, eds. (Washington, DC: ASM Press) pp.847-854.

Sjoholm, A.G., Jonsson, G., Braconier, J.H., Sturfelt, G., and Truedsson, L. (2006). Complement deficiency and disease: an update. Mol Immunol 43, 78-85.

Skerka C., Lauer N., Weinberger A.A., Keilhauer C.N., Sühnel J., Smith R., Schlötzer-Schrehardt U., Fritsche L., Heinen S., Hartmann A., et al. (2007). Defective complement control of factor $\mathrm{H}$ $(\mathrm{Y} 402 \mathrm{H})$ and $\mathrm{FHL}-1$ in age-related macular degeneration. Mol Immuno 44, 3398-3406.

Springer, T.A., Thompson, W.S., Miller, L.J., Schmalstieg, F.C., and Anderson, D.C. (1984). Inherited deficiency of the Mac-1, LFA-1, p150,95 glycoprotein family and its molecular basis. J Exp Med 160, 1901-1918.

Springer, T.A., Miller, L.J., and Anderson, D.C. (1986). p150,95, the third member of the Mac-1, LFA-1 human leukocyte adhesion glycoprotein family. J Immun 136, 240-245.

Stengaard-Pedersen, K., Thiel, S., Gadjeva, M., Moller-Kristensen, M., Sorensen, R., Jensen, L.T., Sjoholm, A.G., Fugger, L., and Jensenius, J.C. (2003). Inherited deficiency of mannan-binding lectin-associated serine protease 2. N Engl J Med 349, 554-560.

Stevens, B., Allen, N.J., Vazquez, L.E., Howell, G.R., Christopherson, K.S., Nouri, N., Micheva, D., Mehalow, A.K., Huberman, A.D., Stafford, B., et al. (2007). The classical complement cascade mediates CNS synapse elimination. Cell 131, 1164-1178.

Sullivan, K.E., Wooten, C., Goldman, D., and Petri, M. (1996). Man- nose-binding protein genetic polymorphisms in black patients with systemic lupus erythematosus. Arthritis Rheum 39, 2046-2051.

Sumiya, M., Super. M., Tabona, P., Levinsky, R.J., Arai, T., Turner, M.W., and Summerfield, J.A. (1991). Molecular basis of opsonic defect in immunodeficient children. Lancet 337, 1569-1570.

Summerfield, J.A., Sumiya, M., Levin, M., and Turner, M.W. (1997). Association of mutations in mannose binding protein gene with childhood infection in consecutive hospital series. BMJ 314, 1229-1232.

Super M., Thiel S., Lu J., Levinsky R.J., and Turner M.W. (1989). Association of low levelsn of mannan-binding protein with a common defect of opsonisation. Lancet. 2, 1236-1239.

Takeda, J., Miyata, T., Kawagoe, K., lida, Y., Endo, Y., Fujita, T., Takahashi, M., Kitani, T., and Kinoshita, T. (1993). Deficiency of the GPI anchor caused by a somatic mutation of the PIG-A gene in paroxysmal nocturnal hemoglobinuria. Cell $73,703-711$.

Tarr, J., and Eggleton, P. (2005). Immune function of C1q and its modulators CD91 and CD93. Crit Rev Immunol 25, 305-330.

Turner, M.W. (2003). The role of mannose-binding lectin in health and disease. Mol Immunol 40, 423-429.

Turner, M.W., and Hamvas, R.M. (2000). Mannose-binding lectin: structure, function, genetics and disease associations. Rev Immunogenet 2, 305-322.

Vorup-Jensen, T., Petersen, S.V., Hansen, A.G., Poulsen, K., Schwaeble, W., Sim, R.B., Reid, K.B., Davis, S.J., Thiel, S., and Jensenius, J.C. (2000). Distinct pathways of mannan-binding lectin (MBL)- and C1-complex autoactivation revealed by reconstitution of MBL with recombinant MBL-associated serine protease-2. J. Immunology 165, 2093-2100.

Yang, Y., Chung, E.K., Zhou, B., Lhotta, K., Hebert, L.A., Birmingham, D.J., Rovin, B.H., and Yu, C.Y. (2004). The intricate role of complement component $\mathrm{C} 4$ in human systemic lupus erythematosus. Curr Dir Autoimmun 7, 98-132

Yang, Z., Mendoza, A.R., Welch, T.R., Zipf, W.B., and Yu, C.Y. (1999). Modular variations of the human major histocompatibility complex class III genes for serine/threonine kinase RP, complement component C4, steroid 21-hydroxylase CYP21, and tenascin TNX (the RCCX module). A mechanism for gene deletions and disease associations. J Biol Chem 274, 12147-12156.

Yu, C.Y., Chung, E.K., Yang, Y., Blanchong, C.A., Jacobsen, N., Saxena, K., Yang, Z., Miller, W., Varga, L., and Fust, G. (2003). Dancing with complement C4 and the RP-C4-CYP21-TNX (RCCX) modules of the major histocompatibility complex. Prog Nucleic Acid Res Mol Biol 75, 217-292. 